\title{
Whaling-the Continuing Slide to Extinction
}

\author{
Richard Fitter
}

At its 30th meeting, in London in June 1978, the International Whaling Commission began to stumble towards its end as a useful regulator of the whale stocks of the world. In classic Parkinsonian style, it has acquired a full-time secretariat and new offices just at the point when, after thirty years' neglect of its duty to conserve the whale stocks of the world, it has almost no function left. Only the sperm whale stocks remain as anything like the basis of a prosperous whaling industry. Small-scale local coastal whale fisheries will no doubt continue for some years; being less efficient, they take longer to exterminate the stocks on which they depend for their livelihood.

Within recent years, the IWC has presided over the reduction of first the blue whale, then the fin whale, and this year the sei whale to a population size which has necessitated them being wholly protected. What were at one time healthy stocks, which could have been harvested on a sustained yield basis, have been destroyed by a combination of scientific ignorance and commercial pressures, and a similar situation has arisen in the North Pacific. Of the Antarctic baleen whales, there remains only the little minke (30ft long compared with the 60-100ft of the three others) and clearly this will soon be brought to a similar plight, since it is the only whale available for the two remaining factory ships (one Russian, one Japanese) in the Antarctic whale fishery. Since we know even less about the stock size of this hitherto neglected species than about the others, it may well not take more than two or three years to bring the minke whale into protected status, which is a euphemism for commercial extinction.

\section{Sperm whale next?}

There will then remain nothing but the sperm whale, still with substantial stocks, which could, if properly managed, still be a valuable resource for mankind. Attention must now be concentrated on preventing the IWC from allowing these stocks to be destroyed also, whether from the failure of its Scientific Committee to fix satisfactory quotas, or from pressure from the two remaining pelagic whaling nations, Japan and the USSR, to allow quotas larger than even the majority of the Scientific Committee is prepared to recommend. Australia has made a good start by closing down its only whale station, at Albany, Western Australia. Conservationists will take heart for the reason given: that the move away from sperm oil to alternatives has already discouraged the company's usual buyers from ordering their supplies forward.

The IWC's agreement, at the insistence of the United States, to a quota of 27 bowhead whales struck or 18 landed, despite the Scientific Committee's recommendation of a nil quota, is also to be deplored. Under political pressure from the Eskimos the US acted in the same way as Japan and the USSR.

The failure of the IWC to address itself to the moratorium was well publicised in the press. When Panama was persuaded to withdraw its motion, the chair ruled that no other country could restore the moratorium to the agenda once it had been withdrawn, yet when, at the end of the meeting, the 


\section{Commercial Whaling}

Quotas for 1978/79

Last year's figures are shown in brackets

Southern Hemisphere
$1978 / 79$

Sperm

Fin

Sei

Bryde's

Minke
(5908)

(5690)
North Pacific
1979

(6444)

(524)

(400)
North Atlantic 1979

685

470

84

0

2552

$\star$ Quotas will be set at a Special Meeting to be held before the season begins.

In addition, blue, right, humpback and bottlenose whales remain protected from commercial whaling in all areas.

USA wanted to reopen the question of the bowhead whale quota, it was allowed to do so-and secured a larger quota.

\section{Aboriginal Whaling}

The Commission decided that for 1979 the catch of bowhead whales from the Bering Sea stock by Alaskan Eskimos should be limited to 27 whales struck or 18 landed, compared with 18 and 12 in 1978.

The North Pacific gray whales were classified as follows:

Eastern Stock

Western Stock
Sustained Management Stock

Protection Stock
Catch Limit 178

Catch Limit 0

178 represents the average kill (by the Soviet aboriginal fishery) over the years 1968-1977.

The Commission reviewed the exemption allowing up to 10 humpbacks to be taken in Greenland waters by aborigines and decided that the fin whale catch limit for the West Greenland stock be increased from 4 to 15, and that the combined limit for humpback and fin whales in these waters shall not exceed 15 whales.

\section{Statement (in part) read by the WWF Representative, Sir Peter Scott, at the opening of the IWC meetings, June 26th, 1978}

'When whaling began in the Southern Ocean it has been estimated that there were more than $1,300,000$ great whales for the whalers to exploit. Almost half of them were sperm whales. Today there are only about 600,000 great whales in the Southern Ocean, and of these 415,000 are sperm, leaving a total stock of only 185,000 blue, fin and sei whales combined. The proportions of the original whale populations surviving in the Southern Ocean are thought to be: $2.5 \mathrm{per}$ cent of blue whale stocks, 19 per cent of fin whale stocks, 50 per cent of male sperm whale stocks, 55 per cent of sei whale stocks, and 78 per cent of female sperm whale stocks. By 1977, all blue whale stocks and the great majority of the southern fin whale stocks, which were until recently the mainstay of the industry, had to be classified as protection stock.

'This is what the whaling industry, over the years, has done to one of the richest natural resources in the world. It is this continuing decline in whale stocks, delayed to some extent by the quotas set by the International Whaling Commission, that forms the basis of the public demand for a moratorium on whaling. The fact that stocks go on falling, despite the quotas set by the 
Commission, is a clear indication that these quotas are still, in general, too high. The excessive quota for North Pacific sperm whales, fixed in Tokyo last December, on the basis of strikingly unsatisfactory data, is only the latest of many unwise decisions. The reason why the quotas are too high is that their data base is wholly inadequate. . . If the Scientific Committee had the courage of its convictions, it would either refuse to set any quotas with such inadequate information, or set quotas with an extremely conservative bias. The continued fall in whale stocks year by year shows how wrong it has been to go on making these over-optimistic assessments.

'Until the data base can be improved, WWF continues to call for a moratorium. Even a moratorium of one year would enable efforts to be concentrated on data gathering. Time is rapidly running out... The present policies are serving the interests neither of the whales, which are steadily becoming commercially extinct, nor of those employed in the whaling industry, who are also being steadily eliminated. It is difficult in fact to see whose interest is being served by the present policies. It seems that whaling is likely to continue unabated until all whale stocks are commercially extinct. This will be the ultimate indictment of the IWC and its policy.'

\section{Statement by the FPS read at the end of the IWC meetings, July 1 1978}

'Death throes are always a painful affair, and the death throes of both the whaling industry and the whale-based Eskimo culture, which we have experienced at this 30 th meeting of the IWC are no exception. Many years of gross over-exploitation are now bringing their inevitable result. Ironically the reaction of those most affected, the Japan Whaling Association and the Eskimos, has been to demand an acceleration of the extinction process in the whale stocks.

'The Fauna Preservation Society deplores both the fixing of an unrealistically high quota for the bowhead whale and the inability of the whalers to see that their only hope of preserving their whaling industry lies in extremely conservative quotas for the sperm whale. The Society believes in the use of wildlife resources for the benefit of the human population of the world. All the IWC has succeeded in doing in the past 30 years is to deprive the world of an extremely valuable natural resource.'

\section{Amazon Pact}

Eight of the nine Amazonian countries have signed an Amazon Pact, pledging to strike a balance between economic development and environmental preservation. The treaty calls for the rational use of native animals and plants as well as joint research into tropical ecology, medicine, agriculture, forestry, fishing, water resources, and power, and emphasises the need for independence from outside interests-by implication the multi-national companies which have been responsible for so much devastation in the region. The eight nations-Bolivia, Brazil, Colombia, Ecuador, Guyana, Peru, Surinam and Venezuela (French Guiana was not represented)-signed the treaty at a ceremony in Brasilia in July 1978. At one of the meetings, Jorge Mantellini of the Venezuelan Foreign Ministry said, 'As we have exclusive jurisdiction over this immense region, so also do we accept and fulfill the responsibility of initiating its development without destroying its ecological balance and of using its immense potential riches in a rational way'. 